\title{
Handling Pandemic in Islamic Literature (Study of The Book "Badzlul Unto Fadhli ath-Thâ'un" by Imam Ibn Hajar al-Asqalani)
}

\author{
Sugeng Hariyadi \\ Universitas Islam Sultan Agung Semarang, Indonesia \\ Email: sugeng_hariyadi@unissula.ac.id \\ Ahmad Muflihin \\ Universitas Islam Sultan Agung Semarang, Indonesia \\ Email: a.muflihin@unissula.ac.id
}

\begin{abstract}
In the gth century of hijri., a big scholar in the field of Hadith, Ibn Hajar alAsqalani has described the guidance of the Shariat in dealing with an pandemic which was packaged in his book "Badzlul Mâ'un fi Fadhli athThâ'un ". This book should be noted through the comparison of the pandemic study between the arguments of the imam with the views of modern scholars, in order to weigh the weight of their respective views. With this comparison, a scientific method of hazanah Islam can be seen in looking at a problematic community that has repeatedly occurred, such as the pandemic COVID-19, as well as connecting the scientific chain and Islamic literature passed down from the Prophet to the next generation, as it is known that the scientific chain known as 'sanad' is part of religion. This research reveals 3 main topics related to pandemic management guidance, namely the validity of syahid status for the dead, the origin of quarantine, and guidance during and after the pandemic.
\end{abstract}

Keywords: Ibn Hajar, Pandemic Handling, Islamic Guidance, Pandemic of COVID-19, Thâ'ûn, Literature

\begin{abstract}
Abstrak
Pada abad ke-9 $H$., seorang imam besar di bidang ilmu Hadits yang bernama Ibnu Hajar al-Asqalani telah mendiskripsikan tuntunan syari'at dalam menghadapi sebuah wabah yang dikemas dalam karyanya dengan judul "Badzlul Mầun fi Fadhli ath-Thâ'un". Sebuah karya yang patut diperhatikan melalui perbandingan studi pandemi antara argumentasi sang imam dengan pandangan para pakar dan ulama modern, dalam
\end{abstract}


Sugeng Hariyadi, Ahmad Muflihin

rangka menimbang bobot pandangan masing-masing. Dengan perbandingan ini, terlihat sebuah metode ilmiah dari hazanah Islam dalam memandang sebuah problematika umat yang berulang kali terjadi, seperti wabah pandemi covid-19 ini, sekaligus menyambung mata rantai keilmuan dan literatur Islam yang diwariskan dari sejak Rasulullah hingga generasi selanjutnya, sebagaimana yang diketahui bahwa mata rantai keilmuan yang dikenal dengan istilah 'sanad' merupakan bagian dari agama. Penelitian ini mengungkap 3 topik pokok yang berkaitan dengan tuntunan penanganan wabah, yaitu keabsahan status syahid untuk korban meninggal, asal usul karantina, dan tuntunan pasca wabah.

Kata Kunci: bnu Hajar, Penanganan Pandemi, Bimbingan Islam, Pandemi COVID-19, Thâ'ûn, Literatur

\section{Introduction}

In keeping with the development of digital information in the context of facing the COVID-19 pandemic, a masterpiece of a high priest of hadith discipline was found, namely imam Ibn Hajar alAsqalani (d. $852 \mathrm{H}$ ) with the title, "Badzlul Mâ'un fî Fadhli athThâ'un". There are two reasons behind why this work is important to be appointed as a research. First, imam Ibn Hajar is a scholar with a myriad of masterpieces that are undoubtedly positioned in the eyes of other scholars and how great his role in the development of Islamic science. Call it his masterpiece, "Fath al-Bâri" a monumental work that directs the book "al-Jâmi' ash-Shahîh" by Imam Bukhari. There are 282 great works inherited by the high priest of this hadith (Al-Asqalani n.d., 21). The Second, although the age of this work has been centuries, namely since the 9 th century $H$., but the content is very interesting to be studied in order to present a shari'a guidance how to respond to the pandemic of this world in accordance with the understanding of salafus shalihin. In addition, it is also an effort to synchronize the understanding of ancient scholars with the views of contemporary scholars and policies implemented by the government (Miftahuddin Azmi 2020, 50)..

In short, this paper presents a number of discussions related to pandemics, among which will be the focal point of this study is why victims of the Muslim pandemic are recognized as martyrs, quarantine provisions of pandemic areas, and what Muslims should do during the pandemic until after completion. These three things are very interesting to be examined in order to know the extent of their views with the views of scholars now. 
Both factors lead to one of the important findings of this study, namely that quarantine or lockdown of areas and or patients in the face of the COVID-19 pandemic is believed to be the right action that has been applied since the time of the prophet Muhammad Saw. and friends. For example, Umar ibn Khattab who was about to enter the region of Sham that was being attacked by the pandemic to kill some friends, such as Abu Ubaidah (R.A). And the second, among the things that may be new found in the object of this study is to take care of each other and save the lives of Muslim brothers or human beings. Ibn Hajar mentioned a medical view in his era that the meeting of dirty air and clean air due to the transfer of a person from the pandemic to a pandemic-free region allows for the onset of new diseases in migrants or locals.

This research is based on qualitative method with a scriptive approach through the following stages: 1) Data collection: Collection of library resources from private libraries and downloading related sources in the form of PDFs; 2) Data processing: Reading of data taken from found sources and translation of Arabic texts into Indonesian, followed by engraving the necessary information; 3) Data preparation: Preparation of data and informs obtained in accordance with the research framework by paying attention to the rules of scientific research to find the preliminary and general results of research. Deeper research on preliminary and general results, complete data and comparative information, to the conclusion of research results and systematic preparation. The variables observed are the book in the title of this study, namely "Badzlul Mâ'un fî Fadhli ath-Thâ'un" by Imam Ibn Hajar al-Asqalani with a choice of 3 special chapters related to the awarding of syahadah for the victims of the COVID-19 pandemic, the history of quarantine patterns, and the guidance of post-pandemic sharia.

In collecting secondary data, researchers listened to a number of videos and studied scientific articles containing the direction of world Muslim institutions and figures. Then, quote and study the statements related to the topic raised. And to analyze the data, researchers translated data that does not speak Indonesian without mentioning the original language so as not to multiply the number of pages. It will also be re-examined whether the data collected is really the result of the person's opinion or influenced by the opinions of experts and scientists, although it does not mention who influenced it. 


\section{Results and Discussion}

Thâ'ûn is one of the causes of Syahadah and Rahmah of Allah

The pandemic is one of the most high in the world. His death was referred to as shahadah (Al-Asqalani n.d., 170). Among the Hadiths of the Prophet that indicate this is: From Anas bin Malik (R.A)., the

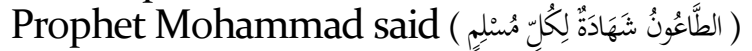

"Thâ'ûn is a syahadah for every Muslim." (By Bukhari, number 2618 and Moslim, number 3540).

Pandemic is also an intermediary of Allah's mercy. (Al-Asqalani n.d.) in accordance with the Hadith narrated by Sayyidah Aisha (R.A):

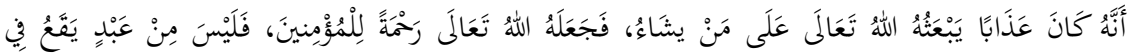

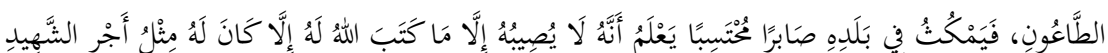

“... That is a punishment which Allah has sent down for those whom He wills, but Allah has made it a mercy for the believers. Then there was not a servant who was afflicted with the disease, and patiently endured in his land, and only hoped for the reward of Allah, surely that nothing had happened to him except what Allah had ordained for him, except that he should receive the reward of syahadah (By Bukhari, number 3474).

Both hadiths are valid hadiths. So it can be recognized that the position of syahadah is really valid for Muslim patients who died from Suffering from COVID-19 or other types of pandemics. People who die from pandemics include syahadah, although their position is not as noble as syahadah because of war and how to handle it is also different. They understand that the true syahadah of the hereafter is the one who died on the battlefield, while the other martyrs are meaningfully majazi. That is not less than the syahadah of war. Therefore, Ibn Hajar classified the title of syahadah as follows: 1) Syahadah of the hereafter, namely the one who died fighting in the way of Allah; 2) The syahadah of the world, the one who fights, but with the intention of obtaining the spoils of war or other worldly purposes; 3) The syahadah of the Hereafter, the martyrs other than the two (Al-Asqalani n.d., 200). 
Terms Recognized as Martyrs for Those Who Died Due to Pandemic

Not all who died from the pandemic included syahadah. Ibn Hajar concluded some conditions of syahadah in accordance with the narration of sayyidah Aisha as follows: 1) Not leaving pandemic territory; 2) Just hoping for the reward of God and His Pleasure; 3) Convinced that if it is dead, then it is because of God's destiny and if it is saved, then also because of God's destiny; 4) Do not lose patience while suffering from pandemics; 5) Relying on God in sickness or health two (Al-Asqalani n.d., 200).

Law Coming In and Coming Out of Pandemic Areas

In sura al-Baqarah verse: 243, Allah almighty tells a villager affected by a pandemic as follows:

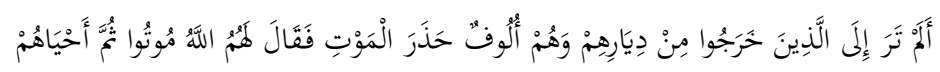

"Knowest thou not those who have gone forth from their homes in the thousands for fear of death, and allah saith unto them: Die! Then He brought them to life." (al-Baqarah: 243)

Ibn Hajar al-Asqalani quoted the story from ibn Abi Hatim through the way of Sa'id ibn Basyir, from imam Qatadah: he said:

"Pes's disease has struck. A third of the population left the stricken village and two-thirds remained. Furthermore, two-thirds of the population followed out until the last three came out. Finally, all the people who came out were affected by the pandemic. And Allah will cause them to die as punishment." (Al-Asqalani n.d., 229-230).

The story shows that getting out of pandemic territory is a prohibition. However, in this case it is uncertain whether the prohibition falls into the category of haram or makruh? Because the verse does not implicitly mention that God forbids them to go out for some reason. God only mentions that when they came out, God punished them with death. The rule of Ushul fiqh states: The basis of the prohibition is to prohibit as long as there is no evidence to indicate to put (Al-Khudhari 2003, 98). 
The question is: Is the punishment because they sin or just because it came out because of a pandemic? The narration cited by Ibn Hajar and al-Baghawi corroborates the second prediction. And to strengthen the validity of the narration, Ibn Hajar mentioned: Isnadnya hasan mursal, Abu Malik named Ghazwan is a generation of young Tabi'in who also narrated from Muslim (Al-Asqalani n.d., 233). As it is known that the law of practicing hadith mursal is valid if narrated by a prominent Tabi'in, especially when strengthened by other histories, made a backup of the majority of scholars, or supported the history of a friend(As-Suyuthi n.d., 1). Thus, the narration can be practiced. Based on these reports and evidence, it can be concluded that exiting the wahab area is haraam if it is believed that it can take lives.

The story of Umar ibn Khattab (R.A). Not So Into The Region Of Sham During pandemic

Ibn Hajar quoted a short story about Umar ibn Khattab (R.A). canceled his pilgrimage to the Levant region because of the pandemic. Among the Narrations he quoted is what was narrated by imam athThahawi with a valid sanad from the friend of Anas ibn Malik (R.A). umar had gone to Syria. Abu Thalhah and Abu Ubaidah ibn al-Jarrah greeted him by saying: "O Amirul mukminin, you are followed by the faces of the companions and the best people of the Messenger of Allah. Come back here next year!" Umar returned home and returned to Syria the following year (Al-Asqalani n.d., 240-241) ( Muhammad Khairul Ulum 2001, 7) .

This narration reinforces the narration mentioned by Ibn Hajar in interpreting the 243rd verse of surah al-Baqarah earlier in terms of the prohibition of entering pandemic areas. So, both entry and exit are equally prohibited.

Before leaving the country of Sham which was affected by the pandemic, Umar had a chance to have a relationship with other friends whether to return to Medina or enter Syria? Some said to him, "Shall we escape from the takidr of Allah?" Umar said, "Yes, but we will escape from a destiny to another. Imagine if your camels were that to two valleys, one fertile and the other barren. Even if you take them to the fertile, then it is also God's destiny. And if thou that unto the barren, it is also because of the destiny of God." But Abdurrahman ibn Auf (R.A). then reminded him with the hadith for the Prophet and umar's entourage did not enter the Sham (Al-Asqalani n.d., 241). 
In this case, it may be reviewed that the history of Umar (R.A). showing that not entering the territory of the pandemic does not mean not believing in the destiny of God, but rather part of the effort to reach the point of true tawakal, because the essential tawakal will not be achieved unless with unanimous confidence after preparing the means and trying as hard as possible to avoid mistakes and pay attention to the benefit. Next, what happens, that's God's destiny. We cannot say that this event is destiny as long as it has not happened. What is the concept of faith in destiny? Al-Marhum Grand Sheikh alAzhar Mahmud Syaltut explained:

"Islam does not tolerate people getting lost or violating the provisions of Allah in the form of commands in the form of berakidah or other religions, then reasoned: this is because it is His destiny. If this is the case, then what is the responsibility of Shari'a revealed? What are the Books and the Prophets sent down for? What is the preaching of mankind to Allah? What is the promise of reward for the doer of good and the threat of punishment for the evil-doer? Surely that is not in accordance with the wisdom of Allah in governing the lives of His creatures"(Syaltut 2017, 78-79).

This discussion will be detailed in the next chapter according to the context of what to do post-pandemic.

Differences of Opinion of Friends About the Need or not Lockdown in pandemic areas in the story of Umar bin Khattab (R.A)

Umar ibn Khattab (R.A). had sent a message to Abu Ubaidah (R.A). to invite their people to leave their pandemic-affected areas. Abu Ubaidah wanted to obey him, but death picked him up first. Then, Amr ibn Ash (R.A). lead the people to leave the region (AlAsqalani n.d., 269).

In response to this direction, Abu Musa al-Ash'ari Ra's friend. understand that the command to Abu Ubaidah (R.A). to leave the region not only to escape pandemic deaths, but to try to save themselves and heal the sick (Al-Asqalani n.d., 273). 
About the sharia law related to in and out of pandemic areas, classical scholars look at how to deal with the ban on exiting pandemic areas as follows:

First: Ibn Abdil Barr said that bubonic plague is a disease that can cause death evenly. Those living in pandemic areas should not leave the region, and those living outside the territory should also not enter the territory. Tajuddin as-Subki in his book states that the prohibition is haram. Abu Musa al-Ash'ari thought it permissible to go out, but for certain purposes, not to escape. The purpose in question is medicine. Ibn Hajar commented on this issue by explaining that going out for treatment is not haraam according to the Shaafa'i and most scholars. And what the scholars argue is that they are out of territory to escape. (Al-Asqalani n.d., 274-275).

Ibn Hajar argued that it is haraam to leave the territory absolutely for no reason, or just to flee. This is corroborated by the narration quoted by imam Ahmad of Aisha (R.A). as follows:

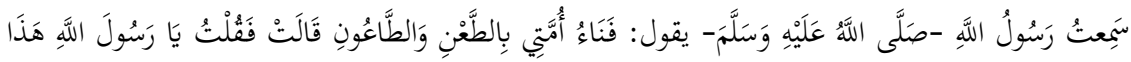

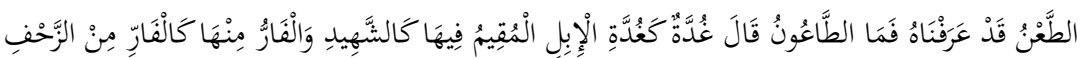

"I heard the Messenger of Allah say: The death of my people is due to a puncture or a pes. Aisha asked: We already know about the puncture, then what is pes? The Prophet replied: "Bubonic plague is like camel bubonic plague. Who stays in his place like a martyr and who goes away like fleeing war." (By Ahmad, number 15055)

In interpreting the attitude of Umar ibn Khattab who did not enter the region of Sham that was affected by the pandemic does not mean to escape from any destiny, but like a person who will enter a burning house and not enter so as not to be stung by fire. This falls into the category of avoiding the cause of destruction (Al-Asqalani n.d., 283) (Al-Asqalani n.d., 282). (Rozi, Masykur, 2020, 213).

Regarding the issue of tawakal level to Allah and trying to avoid disease, Ibn Hajar interpreted the attitude of Umar ibn Khattab (R.A). and other companions that the companions who disagreed with Umar's attitude that canceled the plan to Syria because there was a pandemic based on a full-trust attitude to Allah Almighty, regardless 
of the reasons for trying to avoid. This attitude is often done by some friends. However, Umar preferred to pay attention to the benefit of muslims, although still convinced that everything happened by the power of Allah (Al-Asqalani n.d., 284)

\section{Wisdoms of Prohibition to Come Out of pandemic Areas}

Some scholars consider that the ban on exiting the pandemic area is a form of worship. The proof is to avoid destruction. So, it should be done to get the pleasure of God. This wisdom is in accordance with

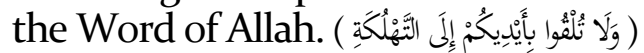

\section{“....Don't cause yourself to fall apart.”. (Al-Baqarah: 195)}

Some scholars mention some of the wisdom of the prohibition as follows: a) Generally, bubonic plague is contagious so anyone is very likely to have contracted it when one of its neighbors has been exposed; b) When healthy and strong people leave, then who will care for and treat people who are sick? The departure of their brethren will surely leave an inner wound and weaken their hopes of recovery. So why leave the pandemic area, while the danger is certain, while the maslahatnya uncertain?! (Al-Asqalani n.d., 302).

Ibn Hajar quoted ibn Mas'ud as saying: "Bubonic plague is a test for those who stay and who want to leave" (Al-Asqalani n.d., 303).

\section{The Wisdom of Prohibition of Entering Pandemic Areas}

God forbids any person from harming himself, even though there is no way out of His way. This is part of a cautious attitude besides protecting yourself from the saying of shirk: Had I not entered the territory, I would not have been sick. And had he not entered, he would not have died (Al-Asqalani n.d.,304). This principle is in accordance with the statement of Allah (S.W.T):

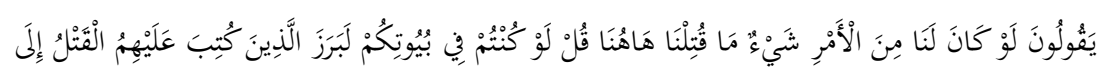

"They say, "If there had been for us anything in this matter, we would not have been killed here." Say, "Even if you had been in your homes, those destined to be slain would have gone forth to the place where they were slain.". (Ali Imran: 154)

Quoting Ibn Daqiq al-Id's explanation, Ibn Hajar stated: Entering the pandemic area is tantamount to delivering yourself to a place of 
disaster. It may not be patient. And the one who flees is like one who flees from destiny.

As a complement, although it can not be used as a benchmark: Medical experts say that the residents of pandemic areas will usually adapt when breathing to the air condition of the region, then begin to get used to such clean air for people far from pandemic. (Al-Asqalani n.d.,306). This is the quote from Ibn Hajar from his understanding of the medical at his time. Whether or not this view is correct, it is appropriate that we refer to a medical expert. However, this view reinforces the prohibition not to leave the pandemic area in unclear, negative or positive circumstances against the disease that is developing it.

\section{Guidance for the General Public, Healthy and Sick}

The prayer that the pandemic be lifted immediately from the Muslims law is permissible in shari'a, both congregational and alone. This view is mentioned by the imam shafi'i and exemplified by imam Rafi'i (perhaps he meant Abdul Karim bin Abil fahdl Muhammad bin Abdil Karim al-Qazwini author of the book "ash-Syarhu al-Kabîr fi Furû'i al-Madzhab) with pandemic and drought(Al-Asqalani n.d., 316).

Medicine and prayer are not contrary to faith in destiny, as mentioned in chapter I. Pandemic pes is one of the diseases that requires us to pray and take refuge in God to be kept away and healed, although any disease can abort sin and cause syahadah (Al-Asqalani n.d., 316-317) (Abdul Fakhri 2020, 416).

With regard to this direction, there are some rumors that reflect jabariyyah (Read: Understanding that believes that all things and deeds of man are doomed and man is forced to live without freedom of choice). Some of them are as follows: a) Pandemic is part of God's compassion. Why pray to be lifted up?; b) People who patiently accept pandemics to death are classified as martyrs. He who rejects it shall be denied a great reward. So, begging to lift the pandemic means working on something that has been obtained and hoping for something impossible; c) Faith in destiny requires us to fully believe that whatever happens is God's will; d) rohibition of syar'i to leave pandemic areas (Al-Asqalani n.d., 319).

Responding to the rumors, Ibn Hajar quoted waliyyuddin alMillawi's opinion in his work "Hallul Hubâ lirtifâ'il Wabâ" as follows: 
a) The prayer for the pandemic to be lifted is a valid prayer in sharia. Therefore, it should not be rejected except by strong shar'i evidence; b) Although as a mercy, but does not mean it should not ask for the pandemic to be lifted. Grace with influence and cause are three different things. What is requested to be lifted is the influence and cause of the grace, while the requested to be revealed is his mercy; c) The one who is considered a martyr because of the pandemic is one who patiently accepts, strives, and whom he hopes is only the pleasure of God. As with the war against the enemy, we are commanded to pray to God to defeat them, as well as the pandemic; d) Believing in destiny does not mean not praying, because if not praying, it will be contrary to the position and fadilat of praying itself, as mentioned in some verses of the Qur'an and sunnah of the Messenger of Allah (AlAsqalani n.d.).

Put your trust right in God during the pandemic

Regarding the opinion that there is no need to pray to avoid the pandemic, Ibn Hajar explained that it is not forbidden nor is it warned. This is in accordance with the prayer of His Majesty the Prophet Muhammad when returning from Taif as follows: ( وَلَكِن عَاِْيَتُكَ (أَوسَعُ ليم

"But, your apologies are broader to me ...". (By Thabrani, number 315)

The requirement to put your trust, but also pray is not to deny the qadha set by Allah and to be sure that Perhaps God ordained a cause of healing for him (Al-Asqalani n.d., 327).

Thus perhaps the essence of the concept of relying on God and believing in destiny and the importance of trying to treat in the context of disease, as explained by imam Ghazali when mentioning the law of medicine and not treating and hiding the disease suffered. It is mentioned that treating with drugs that are really believed to cure the law is mandatory. However, not taking medication is sometimes also considered good because it shows the high level of laughter of a person, even hiding the disease for some people is one of the highest maqam (read: position) in goodness (Al-Ghazali 2003, 207). This explanation combines the history and attitude of the companions in modeling His Holiness the Prophet (s) in accordance with their faith and understanding. 


\section{Increase Shadaqah}

Ibn Hajar quoted Umar ibn Abdul Aziz's message to the local leaders when there was a Wahhab because of the flash floods that hit their region: "Pray in congregation and give Shadaqahto the rich among you. Then recite the prayer as said by the prophet Adam:

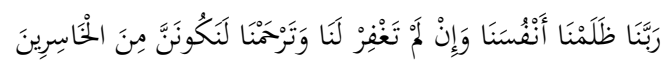

"O our Lord, we have wronged ourselves. And if You do not forgive us and love us, we will be among the losers". (Al-A'raf: 23)" (Farid F. Saenong 2020, 78)

\section{Increase the Reading of Shalawat}

This practice is in accordance with what was quoted from Syihabuddin bin Abi Hajlah in practicing the hadith of the Prophet (S.A.W) that there was someone who asked the prophet: How many times should I recite shalawat to you when praying? After being answered halfway, the person actually asked for more. Until finally, he will pray only by reading shalawat only. At that time, the Messenger of

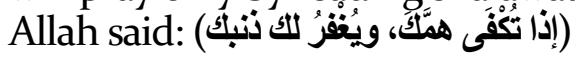

"Then all problems will disappear and your sins will be forgiven". (By Hakim, number 3537) (Al-Asqalani n.d., 333)

Fulfilling the Rights of Others, Seeking Forgiveness, and Repent

Hastening to fulfill rights and settling affairs with others, repenting of all sins and transgressions, and beristigfar from all things that are of no benefit is highly recommended, even required in good health or illness, normal and excluded. And it is more ordered when sick, although the pain is not alarming, and it is highly recommended when it causes death, such as a pandemic (Al-Asqalani n.d., 339). Narrated Abu Hurairah (R.A)., Rasulullah Saw, said about the responsibility for the rights of human slaves:

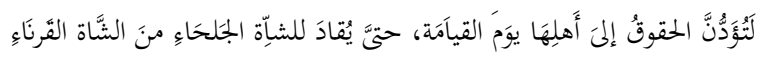

"Those rights will surely be fulfilled for their owners on the Day of Resurrection until the hornless goat will be directed to the horned goat.". (By Muslim, number 4679) 
Promise of Allah (S.W.T). also mentioned for people who beristigfar in the sense of acknowledging mistakes and repent in the sense of beristikamah carry out religious guidelines that they will get great blessings of this world and the hereafter as follows:

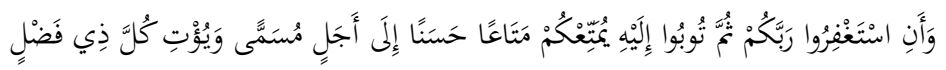

"And ask forgiveness of your Lord, then repent to Him, He will give you a good favor until the appointed term and will give His great bounty to whoever does good.". (Hud:3)

\section{Ban Challenging Pandemic}

Among the arguments that show that medical treatment is required is to be careful during a pandemic against the recommendations of doctors, such as removing feces, reducing food, leaving sports, bathing, staying at home, and not breathing a lot of contaminated air (Al-Asqalani n.d., 340).

Prayer for God to heal and protect from disease

Allah (S.W.T). said to command us to always pray fervently 'and

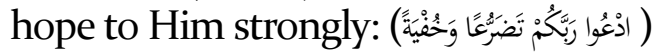

"Pray to your Lord with submission and fear". (Al-A'raf: 55)

\section{Patience with Destiny}

Narrated Shuhaib (R.A)., He said: The Messenger of Allah (may peace be upon him) said to motivate his people that in every condition, the believer always gets the reward of Allah (S.W.T):

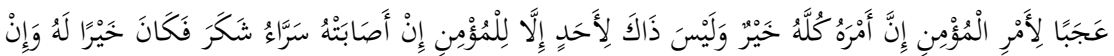

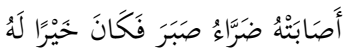

"How amazing is the condition of the believer! Because every situation is good for him. And that is not obtained except by those who believe. If he gets good, he will be grateful and that must be good for him. And if he experiences something bad, he will be patient and that's certainly good for him". (By Muslim, number 5318) (Al-Asqalani n.d., 349) 
Husnudzon against the provisions of Allah (S.W.T)

This attitude is more demanded when you are sick. The trick is to remember how low and small and weak humans are as part of Allah's creatures. Meanwhile, Allah's mercy is very broad and does not want to torture His servants. Also by acknowledging his sins and negligence, then believing that no one will be able to help him without Allah's permission, then followed by remembering and contemplating the verses about Allah's mercy and His vast forgiveness (Al-Asqalani n.d., 351) (Hanna Oktasya Ross 2020, 77).

The Position of the Martyr Due to the Pandemic, Handling of Patients who Died Due to COVID-19, and Interaction with Patients' Families

Ibn Hajar has confirmed that the patient died due to the pandemic including the syahadah of the afterlife. How does contemporary fiqh view this status? Al-Azhar International Digital Fatwa Center mentions the fatwa related to this is not much different from the views of Ibn Hajar mentioned above as follows:

"The al-Azhar International Digital Fatwa Center issued a fatwa on the obligation to stay at home during the outbreak of the pandemic except for urgent needs, and conveyed the promise of reward for those who stay at home patiently and satisfied with Allah's provision that they will get the reward of a martyr, even if they do not die from the pandemic" ( Al-Azhar International Digital Fatwa Center, 45).

The Fatwa Center also issued illegal fatwas that violated medical directives and preventive protocols issued by the authorities and doctors, because they were considered harmful to themselves and others. This is in accordance with the Hadith narrated by Jundub bin Hudhaifah (R.A). as follows:

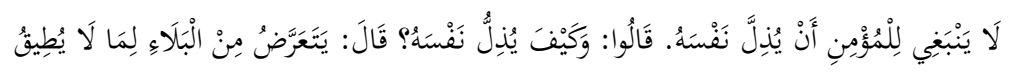

"The believer should not humiliate himself. They said: How can he humiliate himself? He said: by endangering himself to meet a disaster that he is not able to face". (By Turmudzi, number 2180 and recognized as Hadith hasan gharib)

In another fatwa, the al-Azhar Digital Fatwa Center also issued a fatwa on the right of patients to die due to COVID-19, namely to be 
bathed, inflicted, dishalati, and buried, although considered a martyr, but a martyr of the hereafter, not the afterlife, such as martyrs of war. ( Al-Azhar International Digital Fatwa Center, 101). In addition, the alAzhar Digital Fatwa Center also explained the procedure for bathing patients who died due to COVID-19. And here's a summary of how to bathe it: a) A special team for bathing, shrouding, and burying. The conditions are: know and implement health protocols and procedures for Islamic law related to the three guidelines; b) If it is not handled by a special team and the body is handed over to the family, then the family simply pours water on the corpse without touching the skin. Of course, you must apply health protocols: spraying disinfectants to sterilize rooms in the house, and wearing complete personal protective equipment (PPE); $\mathrm{c}$ ) If it is not possible to pour water, then tayamum is enough; d) If tayammum is not possible because it touches the skin directly, then by touching a dusty cloth even though it is thin to the face and hands of the corpse.

Wrap the corpse with a strong cloth if it is feared that it will leak fluid ( Al-Azhar International Digital Fatwa Center, 104) (Dzulkifli Noor 2020,9). This procedure is almost the same as what is issued by the Indonesian Ulema Council (MUI). The difference is whether or not the family can bathe and bury the corpse of COVID-19 in accordance with the conditions and medical instructions? What if tayamum is not allowed?

The following is a fatwa issued by MUI on who is allowed to take care of the remains: " Management of corpses (tajhiz al-jana'uz) exposed to COVID-19, especially in bathing and ablution should be done in accordance with medical protocols and performed by the authorities, keeping in mind the provisions of Shari'ah. Meanwhile, to pray and bury it is done as usual by keeping it from being exposed to COVID-19" (Indonesian Council of Ulama 2020, 18).

In this case, MUI does not allow anyone to bathe the corpse except for the medical team that has been determined. And the following is the MUI fatwa regarding the procedure for bathing the bodies of COVID: a) The body is bathed without having to be undressed; $b$ ) The officer must be of the same sex as the body being bathed or shrouded; c) there is no one of the same gender who is bathing, then the officer 
who bathes is there, provided that the body is washed and still wears clothes. If not, then it will be announced; d) The staff cleans najis (if any) before bathing; e) Officers bathe the corpse by pouring water evenly throughout the body; $f$ ) If the opinion of a trusted expert is that it is impossible to wash the body, then it can be replaced with tayamum according to the provisions of the Shari'a, namely: 1) Wipe the face and hands of the corpse at least up to the wrist with dust; 2) For the sake of self-protection when wiping, officers continue to use PPE 3) If according to the opinion of a trusted expert that bathing or immersing is impossible because it endangers the officers, then based on the provisions of the syar'iyah emergency, the body is not bathed or buried. (Indonesian Council of Ulama's Fatwa, 18).

Here, the MUI does not mention the step of using a dusty cloth if tayammum is not possible. With regard to the case of dumping the bodies of COVID-19 patients in the streets or in the open because no one dared to take care of them and some even burned them in some countries, the al-Azhar Digital Fatwa Center also issued the following directives: "The basic principles of Islamic law in terms of this is the person who dies is as noble as the glory of the living, must be treated with dignity and forbidden to be left humiliated. Among the ways to glorify the corpse are bathing, burying, and burying. Burying a corpse according to the agreement of legal scholars is fardhu kifayah. Therefore, one should not allow the corpse of a COVID-19 patient and should not burn it because it is contrary to that glory. The steps to bury him are to impose APD, sterilize the body, put it in a close coffin and dig a deep hole as well as minimize condolences".(Al-Azhar International Digital Fatwa Center, 105-106). These steps are exactly as they are in the MUI's fatwa (Indonesian Council of Ulama 2020, 18).

With regard to some countries that mass bury COVID-19 patients to minimize land, the al-Azhar Digital Fatwa Center also issued a fatwa allowing it with the following provisions: The principle of burial in Islam is that each body has one grave. However, in times of urgency such as natural disasters or pandemics that cause the death of many people and it is difficult to separate each corpse with one grave, the consensus of the four madhhab scholars is to allow mass graves. This is for reasons of urgent conditions, not burdening the management of large costs, and the principle of making things easier. (Al-Azhar International Digital Fatwa Center, 106-107). 
This fatwa is based on the Hadith narrated from Abdurrahman ibn Ka'ab ibn Malik and Jabir ibn Abdullah (R.A), That the Prophet SAW himself had gathered the two martyrs of the battle of Uhud in one garment, then said: Who among the two who memorized the Qur' an more? The companions pointed to one of them, then the Prophet preceded the person and said: "I will be a witness for them all on the Day of Resurrection". (By Bukhari, number 1257) This fatwa is also as issued by the Indonesian Ulema Council (Indonesian Ulema Council 2020, 18).

In other cases, some people refuse the bodies of COVID-19 patients to be returned and buried in their environment. It is stated that it is not permissible to take away the right of the deceased's family to receive and bury the body in a place that has been determined by the family. It's enough how hard it is for them to feel the sadness of losing their family and not being able to witness their final moments. Precisely the obligations of fellow Muslims and humans are condolences, helping, encouraging, and praying for the dead and the left behind ( Al-Azhar International Digital Fatwa Center, 110) ( Maula Sari 2020, 63)..

Ibn Hajar also mentioned that one of the lessons of the ban on going out of the pandemic area is to guard and protect and help relatives in the area, both sick and healthy. This view is in accordance with the fatwa issued by the al-Azhar Digital Fatwa Center regarding the phenomenon of society isolating COVID-19 sufferers and families. It stated: "Isolating someone is a form of humiliation and violation of the rights of individuals and communities, affecting their physical and mental health. Very bad of course. It is even worse if the patient who is being treated is a disease patient who is destined to suffer from that disease. This is in accordance with the prohibition against harming each other, both physically and non-physically. In a Hadith, the Prophet SAW. forbade the companions to stare at the disease for a long time of people suffering from leprosy because it might offend the

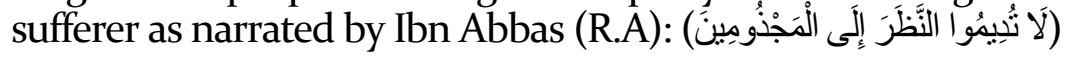

"Don't stare at people with leprosy for too long! " (By Ibnu Majah, number 3533) 


\section{Quarantine During a Pandemic}

Ibn Hajar has discussed the quarantine law a lot during the pandemic when he explained Umar bin Khattab's attitude not to enter the Sham region because of the pandemic and even mentioned some of the lessons. The al-Azhar Digital Fatwa Center also issued a statement confirming this view as follows: "Islamic Shari'a makes the protection of life one of the most important aims and objectives of Shari'a. Therefore, all preventive measures in order to maintain life and safety are prescribed. Quarantine is part of that way when it comes to infectious diseases. Because it can prevent the spread of infectious diseases. Islam ordered it and the Messenger of Allah. Implemented it since one thousand four hundred years ago. The implementation of mandatory legal quarantine during a pandemic does not mean completely reducing the rights of human freedom, but as a form of mercy for all people, so that the common and personal benefit is fulfilled, in accordance with fiqh rules: that danger must be eliminated. Among the hadith narrations that are used as evidence for quarantine is what Amr bin Syarid narrated from his father, he said: There was one of the guests of the Tsaqif tribe who was sick with

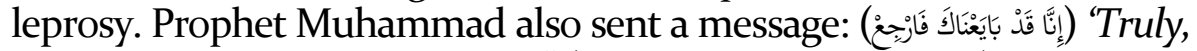
we have baited you. Come back!'” (By Muslim, number 4138)

\section{The Virtue of Shadaqah in the Time of a Pandemic}

Ibn Hajar has mentioned that one of the steps in dealing with and responding to a pandemic, both when it occurs and after it is to increase shadaqah. With regard to this guidance, the al-Azhar Digital Fatwa Center also mentions several fatwas as follows:

Accelerating zakat during a pandemic is legal, even including part of a good religious understanding and a commendable attitude considering the urgent need for weak people who are directly affected by the pandemic. This is in accordance with the narration which states that Abbas bin Abdul Muthallib (R.A). asked the Prophet Muhammad. to accelerate the disbursement of zakat before one year. The Prophet allowed it. (By Ahmad, number 822) (Al-Azhar International Digital Fatwa Center, 118) The fatwa of the Indonesian Ulema Council also stated the same opinion ( Indonesian Ulema Council 2020, 23). 
Some Muslims think that non-Muslims are not entitled to receive social assistance from Muslims because of different religions, with the proposition "al-walâ' wal barâ" (read: loyal to Muslims and stay away from non-Muslims). This is not true, especially during a pandemic. AlAzhar Digital Fatwa Center states: Giving charity to non-Muslims is a good thing that Allah has ordered, because there are elements of help and sympathy. This is as exemplified by Umar bin Khattab (R.A). while giving food to a male Jewish beggar. At that time, Umar walked and (S.A.W) the man begging. He asked: Why are you here? He replied: I am a Jew begging people for Shadaqahto feed my family. At that time, Umar took the man to his house and fed him, then directed him to the treasurer of the Baitul Mal. Umar said to his treasurer: Give a special share for this person and the like that can provide for him and his family from the Baitul Mal property. Umar also said to the Jewish man: "We must be unfair when we only take advantage of your old age, then take tribute from you!" ( Al-Azhar International Digital Fatwa Center, 120).

Al-Azhar Digital Fatwa Center million mentions the recommendation to give more charity during the pandemic as follows: A shared obligation during a crisis like this is to check the condition of relatives, acquaintances, neighbors and employees, and help them as much as possible with money and food. Because the reward of Shadaqahis great, and even greater in times of crisis. This is as narrated by Abu Hurairah (R.A). that a man who came to ask the Messenger of Allah: What charity has the greatest reward? The Prophet replied:

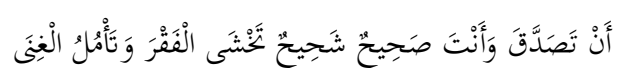

"Alms when you are healthy and generous, but worry about being poor and hope to be rich". (By Bukhari, number 130 and Moslim, number 1713)

\section{The Concept of Tawakal in Facing a Pandemic}

Ibn Hajar has discussed that one of the steps of Islamic guidance in dealing with the pandemic and post-pandemic period is to put your trust in Allah, whether healthy or sick, difficult or happy. Regarding the history of Umar bin Khattab who did not enter the territory of Sham, it was also part of the tawakkal. This view is as explained by the 
Al-Azhar Digital Fatwa Center as follows: In this case it needs to be emphasized that the trust of a servant to Allah his Lord does not conflict with His command to try and look for worldly causes that are legitimate according to the Shari'a. In fact, seeking the cause is part of the perfection of tawakkul. Allah Himself commands both as mentioned in His word which mentions the command to seek sustenance:

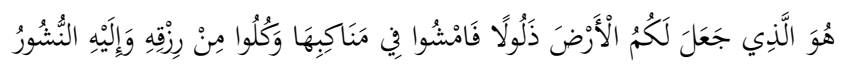

"He it is Who made the earth for you a place of submission. So walk on it and eat of its sustenance and to Him is the gathering of all". (al-Mulk: 51)

The second is the Hadith narrated by Muadz bin Jabal (R.A). which contains a prohibition to simply surrender without effort:

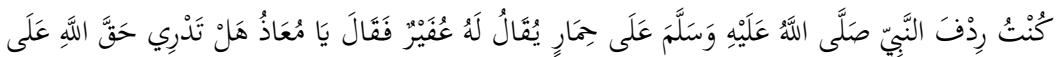

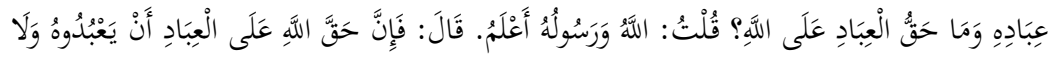

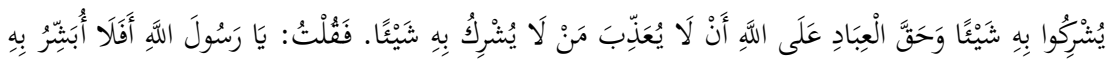

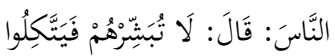

"I was behind Rasulullah Saw. who was riding a donkey known as Ufair. He said: O Muadz, do you know what is the right of God that His servants must fulfill? And what is the right of a servant that God must fulfill for him? I said: Allah and His Messenger know best. He said: The right of Allah over His servants is that they worship only Allah and do not associate anything with Him. And the right of the servants of God is not to punish those who do not associate anything with Him. I said: O Messenger of Allah, may I convey this news to the people? The Prophet said: Do not tell them, because they may surrender without trying!" (By Bukhari, number 2644 and Moslim, number 44) (Al-Azhar International Digital Fatwa Center, 31-32). 


\section{Conclusion}

Based on the above discussion it can be concluded that Ibn Hajar al-Asqalani has presented a fairly comprehensive Islamic guidance in dealing with pandemics at the time. However, there are still many modern steps that have not been mentioned, both in relation to the guidance of the source of the Qur'an and the sunnah or related medical discoveries.

The three main discussions presented by Ibn Hajar as the core discussion of this study offer the reader the shari'i validity that people who die due to exposure to pandemics, such as Thâ'ûn and COVID-19 include syahadah, although not including syahadah of the afterlife and get rewards and a glorious position in the eyes of God like a man who dies fighting in the way of God. Although in the handling of the corpse is different.

Quarantine or lockdown measures for someone or an area affected by a pandemic such as COVID-19 are also steps in accordance with Islamic law. The conclusion is drawn from the history of the story of Umar bin Khattab who was about to enter the region of Sham which was being attacked by a pandemic that killed several friends, such as Abu Ubaidah (R.A). In this case, the legal quarantine is mandatory if it is believed that it can actually endanger life. Except if it is for medical purposes or it is certain that it will not transmit or be infected.

There are many lessons from the laws enacted during such a pandemic. Among them, the most important thing is to take care of each other and save the lives of Muslim brothers or humans. Doctors in the era of Ibn Hajar mentioned that the meeting of dirty and clean air can cause illness in some people who move or come from a pandemic area to a clean area and vice versa. This view leaves the task of confirming the modern medical view. A hope of course there are those who are willing to reveal the truth or error of this view.

Regarding the steps taken in accordance with Islamic guidance at the time of the pandemic, Ibn Hajar mentioned several important steps for all Muslims, namely: Increasing prayers, shadaqah, fulfilling the rights of others, beristigfar and repentance, blessings, trust, and prohibition of challenging the pandemic. He also mentioned two special guidelines for those who suffer from illness, namely to be patient with destiny and berhusnudzan to the provisions of God Almighty. This guidance is taught in order to instruct Muslims that a 
test like a pandemic for them is one of the forms of Allah's mercy. in order to raise his rank in the eyes of Allah (S.W.T).

Ibn Hajar's views proved to be in line with the views of Al-Azhar Digital Fatwa Center International, especially in relation to the three discussions. This shows the credibility of Ibn Hajar's knowledge which may be one of the references of the latest fatwa institutions in dealing with pandemics and directing the people in accordance with the requirements of Islamic law.

\section{REFERENCES}

Al-Asqalani, Ibnu Hajar. Badzlul Mầun Fî Fadhli Ath-Thâ'un. ed. Ahmad Isham Abdul Qadir al-Katib. Riyadh: Dârul Ashimah.

Al-Asqalani, Ibnu Hajar. Badzlul Mâ'un Fî Fadhli Ath-Thâ'un. ed. Ahmad Isham Abdul Qadir al-Katib. Riyadh: Dârul Ashimah.

Al-Baghawi. 1997. Ma'âlim at-Tanzîl. ed. Muhammad Abdullah anNamr. Kairo: Daru ath-Thibah.

Al-Ghazali. 2003. Ihyâ'u Ulûmiddin. Kairo: al-Maktabah atTaufiqiyyah.

Al-Khudhari, Muhammad. 2003. Ushûl Al-Fiqh. Kairo: Darul Hadîts.

As-Suyuthi. Syarhul Muhadzdzab. Kairo: Darul Fikr.

Azmi, Miftahuddin. COVID-19, Media Sosial dan Moderasi Beragama di Indonesia. Book Series: Kampus Merdeka (1). Kampus Merdeka Seri 1 : Menilik Kesiapan Teknologi Dalam Sistem Kampus - Google Buku.

Fakhir, Abdul dkk. 2020. Ritual Ibadah sebagai Upaya Penurunan Kecemasan pada Masa Pandemi Covid-19. Psisula. Prosiding Berkala Psikologi (2). Fakhri | Psisula: Prosiding Berkala Psikologi (lppm-unissula.com).

Lembaga Darul Iftâ' Mesir. 2020. 'ad-Dalîl asy-Syar'i lit-Ta'âmul ma'a Corona al-Mustajad (Covid-19) (Kairo: Markaz al-Azhar alAlami lil Fatâwâ al-Iliktruniyyah). 
Pusat Fatwa Digital al-Azhar. ad-Dalîl asy-Syar'i fi at-Ta'âmul ma'a Vîrus Corona al-Mustajad (COVID-19). Kairo: Markaz al-Azhar al-Alami lil Fatâwâ al-Iliktruniyyah.

Majelis Ulama Indonesia. 2020. "Fatwa Majelis Ulama Indonesia Nomor: 23 Tahun 2020 Tentang Pemanfaatan Harta Zakat, Infak, Dan Shadaqah Untuk Penanggulangan Pandemi Covid19 Dan Dampaknya." https://mui.or.id/wpcontent/uploads/2020/o5/Fatawa-MUI-Nomor-23-Tahun2020-tentang-Pemanfaatan-Harta-ZIS-untuk-PenanggulanganPandemi-Covid-19-dan-Dampaknya.pdf (June 2, 2021).

Noor, Dzulkifli. 2020. Sikap masyarakat dalam Melaksanakan Fatwa MUI tentang Pandemi Covid-19. Jurnal Emanasi (3). Emanasi : Jurnal Ilmu Keislaman dan Sosial (adpiks.or.id)

Ridho, Muhammad Rasyid. 2020. Wabah Penyakit Menular dalam Sejarah Islam dan Relevansinya dengan Covid-19. Juspi: Jurnal Sejarah Peradaban Islam (4). JUSPI (Jurnal Sejarah Peradaban Islam) (uinsu.ac.id).

Ross, Hanna Oktasya dkk. 2020. Implementasi Konsep Sahdzan (Sabar Dan Huznudzan) Sebagai Upaya Perawatan Kesehatan Mental Di Masa Pandemi Covid-19. Khazanah: Jurnal Mahasiswa (12). Khazanah: Jurnal Mahasiswa (uii.ac.id).

Rozi, Masykur. 2020. Siyasah Pandemic Umar bin Khattab (Health Politics of Umar bin Khattab in Facing the Plague Amwas Years 17-18 H / 638-639 AD). Jurnal Hukum Islam (18). JHI: JURNAL HUKUM ISLAM (iainpekalongan.ac.id).

Saenong, Farid F dkk. 2020. Fikih Ibadah: Beribadah di Masa Wabah. Jakarta Selatan: Nuo Publishing.

Sari, Maula. 2020. Fenomena Penolakan Jenazah Covid-19 Perspektif Hadis di Indonesia. Mashdar: Jurnal Studi al-Qur'an dan Hadits (2). Mashdar: Jurnal Studi Al-Qur'an dan Hadis (uinib.ac.id).

Sanusi, Ahmad. 2020. Teori Maqoshid Syariah dan Penerapannya 
pada Fatwa Korona (Studi Analisis Kritis). Syakhsia: Jurnal Hukum Perdata Islam (21). Syakhsia : Jurnal Hukum Perdata Islam. (uinbanten.ac.id).

Syaltut, Mahmud. 2017. Al-Islâm Aqidatun Wa Syarîatun. Kairo: Majma' Buhuts al-Islâmiyyah.

Ulum, Muhammad Khairul. 2001. Wabah Tha'un Amawas Pada Masa Khalifah Umar Bin Khattab dan Dampaknya. Skripsi. Wabah Tha'un Amawas Pada Masa Khalifah Umar Bin Khattab dan Dampaknya - (uinbanten.ac.id) 